\title{
Expanding the scale of aquatic sciences: the role of the National Ecological Observatory Network (NEON)
}

\author{
Keli J. Goodman ${ }^{1,4}$, Stephanie M. Parker ${ }^{1,5}$, Jennifer W. Edmonds ${ }^{2,6}$, and Lydia H. Zeglin ${ }^{3,7}$ \\ ${ }^{1}$ National Ecological Observatory Network, $168538^{\text {th }}$ Street, Suite 100, Boulder, Colorado 80301 USA \\ ${ }^{2}$ University of Alabama, Department of Biological Sciences, 2098 Bevill Building, Tuscaloosa, Alabama 35487 USA \\ ${ }^{3}$ Department of Crop and Soil Science, Oregon State University, 3017 Agriculture and Life Sciences Building, Corvallis, \\ Oregon 97330 USA
}

\begin{abstract}
The current and future direction of aquatic ecological research leans toward addressing questions that cover multiple scales and levels of complexity. Historically, the ability to do comparative aquatic research across large spatial and temporal scales has been impeded by a lack of comparable measurements, standard methods, and a well organized data management and retrieval system. The National Ecological Observatory Network (NEON) is the first continental-scale ecological observation system designed to collect and provide freely available data on the drivers and responses of ecological change. In this paper, we describe past and present attempts to work across multiple scales in aquatic ecology, and the potential use of NEON aquatics data and infrastructure by researchers to integrate and expand ecological research programs and address novel ecological questions.
\end{abstract}

Key words: aquatic ecology, NEON, large scale, networks, microbial ecology, large river ecology

The greatest challenge faced by ecological researchers is the ability to detect drivers and responses to environmental change across large spatial and temporal scales. Aquatic systems are intimately linked to the surrounding terrestrial environment (Hynes 1975), so they are excellent indicators of changes occurring within and across atmospheric, terrestrial, and aquatic boundaries (Williamson et al. 2009). However, integration of landscape processes requires that ecologists can understand, detect, and predict how large-scale changes will affect aquatic processes and alter ecosystem structure, function, and services (e.g., drinking water, sport fisheries).

The International Biological Program (IBP; 1964-1974; Table 1) was the first large-scale, long-term ecological research program after the International Geophysical Year effort (1957-1958). The IBP supported collection and distribution of scientific data globally, united scientists, and promoted 'Big Science,' and encouraged work across na- tions and disciplines to address ecological questions spanning greater spatial and temporal scales than previously considered. The IBP ended in 1974 after failing to create an organized data-management system and comprehensive biological models (Aranova et al. 2010). However, the program highlighted the need to evaluate long-term ecological change. The US National Science Foundation (NSF) later initiated the Long-Term Ecological Research (LTER) program (Table 1), designed to capture long-term changes across multiple spatial scales (Hobbie et al. 2003). In 1963, Hubbard Brook researchers used a small watershed approach to study nutrient retention, fluxes, and cycling (Bormann and Likens 1969, Likens et al. 1977) and presented streams as indicators of whole-ecosystem function. In 1968, the Experimental Lakes Area (ELA), a long-term monitoring and ecosystem-scale lake experiment was established (Johnson and Vallentyne 1971) to evaluate whole-system function.

E-mail addresses: ${ }^{4}$ kgoodman@neoninc.org; ${ }^{5}$ sparker@neoninc.org; ${ }^{6}$ Present address: Nevada State College, Physical and Life Sciences, 1125 Nevada State Drive, Henderson, Nevada 89002 USA, jennifer.edmonds@nsc.edu; ${ }^{7}$ Present address: Division of Biology, Kansas State University, 116 Ackert Hall, Manhattan, Kansas 66506, lzeglin@gmail.com

"BRIDGES is a recurring feature of FWS intended to provide a forum for the interchange of ideas and information relevant to FWS readers, but beyond the usual scope of a scientific paper. Articles in this series will bridge from aquatic ecology to other disciplines, e.g., political science, economics, education, chemistry, or other biological sciences. Papers may be complementary or take alternative viewpoints. Authors with ideas for topics should contact BRIDGES Co-Editors, Ashley Moerke (amoerke@lssu.edu) and Allison Roy (aroy@eco.umass.edu).

DOI: 10.1086/679446. Received 30 September 2013; Accepted 28 April 2014; Published online 12 November 2014.

Freshwater Science. 2015. 34(1):377-385. ๑ 2015 by The Society for Freshwater Science. 
Table 1. Examples of large-scale aquatic ecological programs. Chl $=$ chlorophyll $a$, EMAP $=$ Ecological Monitoring and Assessment Program, EPA = US Environmental Protection Agency, GLEON = Global Lake Ecological Observatory Network, IBP = International Biological Program, LTER = Long-Term Ecological Research, NARS = National Aquatic Resource Surveys, NAWQA = National Water-Quality Assessment, NSF = National Science Foundation, OECD = Organization for Economic Co-Operation and Development, PI = principal investigator, USGS = US Geological Survey, WISE = Water Information System for Europe.

\begin{tabular}{|c|c|c|c|c|}
\hline Program & Location & Impact & Duration & Key data \\
\hline IBP & $\begin{array}{l}\text { North America, } \\
\text { Europe, Australia }\end{array}$ & $\begin{array}{l}5 \text { biome studies, tracers for } \\
\text { nutrient and energy-flow } \\
\text { experiments }\end{array}$ & 1964-1974 & $\begin{array}{l}\text { Grassland Biome Project, } \\
\text { Eastern Deciduous Forest } \\
\text { Biome Project }\end{array}$ \\
\hline $\begin{array}{l}\text { OECD } \\
\text { eutrophication } \\
\text { modeling }\end{array}$ & $\begin{array}{l}18 \text { countries (US, } \\
\text { Canada, Australia, } \\
\text { Japan, and } 14 \\
\text { western European } \\
\text { countries); lakes and } \\
\text { reservoirs, mostly } \\
\text { temperate zone, } \\
\text { some alpine, arctic, } \\
\text { and subtropical }\end{array}$ & $\begin{array}{l}\text { International effort to establish a } \\
\text { basis to control eutrophication } \\
\text { of inland waters and to develop } \\
\text { guidelines for fixing nutrient } \\
\text { loading criteria compatible } \\
\text { with water-use objectives; } \\
\text { P-loading reduction; } \\
\text { eutrophication management } \\
\text { strategies }\end{array}$ & $1970 \mathrm{~s}$ & $\begin{array}{l}\text { Relationships between nutrient } \\
\text { loading and water-quality } \\
\text { metrics (chl, Secchi depth, } \\
\mathrm{O}_{2} \text { depletion); predictive } \\
\text { eutrophication relationship } \\
\text { models }\end{array}$ \\
\hline LTER network & $\begin{array}{l}\text { Continental US, Alaska, } \\
\text { Caribbean and Pacific } \\
\text { Islands, Antarctica }\end{array}$ & $\begin{array}{l}\text { Wide variety of projects from } \\
\text { nutrient addition to ecosystem } \\
\text { function }\end{array}$ & 1980-present & $\begin{array}{l}\text { NSF-funded, PI-driven } \\
\text { research projects and } \\
\text { publications }\end{array}$ \\
\hline GLEON & $\begin{array}{l}\text { Lakes worldwide } \\
\text { (6 continents) }\end{array}$ & $\begin{array}{l}\text { Grassroots network of ecologists } \\
\text { and limnologists, network of } \\
\text { instrument platforms and sensors } \\
\text { around the world, connected } \\
\text { by cyberinfrastructure }\end{array}$ & 2005-present & $\begin{array}{l}\text { International sensor-derived } \\
\text { data sets, web portal }\end{array}$ \\
\hline EMAP & $\begin{array}{l}\text { Continental US, Alaska, } \\
\text { Hawaii, Puerto Rico, } \\
\text { Pacific Islands }\end{array}$ & $\begin{array}{l}\text { Assess status and trends of } \\
\text { US streams, ecological } \\
\text { risk assessment }\end{array}$ & $\begin{array}{l}\text { 1990-2006 } \\
\quad \text { (rolled into } \\
\text { NARS in 2006) }\end{array}$ & $\begin{array}{l}\text { Rapid Bioassessment } \\
\text { Protocols }\end{array}$ \\
\hline EPA NARS & $\begin{array}{l}\text { Continental US, Alaska, } \\
\text { Hawaii, Puerto Rico, } \\
\text { Pacific Islands }\end{array}$ & $\begin{array}{l}\text { First large-scale study using } \\
\text { statistically valid survey } \\
\text { techniques; standardized field } \\
\text { and laboratory methods to yield } \\
\text { unbiased estimates of the } \\
\text { condition of rivers and streams, } \\
\text { lakes, wetlands, and coastal } \\
\text { waters }\end{array}$ & 2006-present & $\begin{array}{l}\text { Includes National Rivers } \\
\text { and Streams Assessment } \\
\text { and National Lakes } \\
\text { Assessment }\end{array}$ \\
\hline USGS NAWQA & Continental US & $\begin{array}{l}\text { Provide information on the } \\
\text { condition and sustainability } \\
\text { of our nation's water supply }\end{array}$ & 1991-present & $\begin{array}{l}\text { Comparable information on } \\
\text { water resources in } 60 \text { river } \\
\text { basins and aquifers }\end{array}$ \\
\hline WISE & Europe & $\begin{array}{l}\text { Web portal to bring together } \\
\text { water-research data }\end{array}$ & 2007-present & $\begin{array}{l}\text { Interactive public } \\
\text { access to data }\end{array}$ \\
\hline
\end{tabular}

Ecosystem variability makes it necessary to incorporate heterogeneity in hydrologic (Beven et al. 1988, McDonnell et al. 2007), habitat (Palmer and Poff 1997), or landscape patterns (Scarsbrook and Townsend 1993, Huryn et al. 2005) in aquatic ecosystem studies to transition from small, patch-scale studies to large, watershed analyses (Allan and Johnson 1997, Fisher et al. 1998). Integrating variability and heterogeneity into predictive modeling (McClain et al. 2003) is essential in addressing the "Grand Challenges in Environmental Sciences" and predicting responses to change across multiple scales (NRC 2001).

Temporal and spatial variability of ecosystems have long been pivotal foci in ecology (Hobbie et al. 2003). Spa- tial variability at the landscape scale has been addressed by using geomorphologic and environmental gradients to predict community structure and function (Hynes 1975, Vannote et al. 1980), habitat templates based on physical characteristics of watersheds (e.g., slope, canopy cover; Frissell et al. 1986), and gradients of environmental severity (Southwood 1988). Within ecosystems, the effects of top-down and bottom-up control on stream or lake ecosystem structure (Carpenter et al. 1987, 2001, Pace et al. 1999) and function (Paine 1980, Power et al. 1988, Rosemond et al. 2001) are well documented. However, studies done at larger spatial and temporal scales, such as the US Geological Survey (USGS) National Water-Quality 
Assessment (NAWQA; Hirsch et al. 1988), US Environmental Protection Agency (EPA) Environmental Monitoring and Assessment (EMAP; Messer et al. 1991), and National Aquatic Resource Surveys (NARS) programs (Table 1), tend to concentrate on stream health and monitoring rather than on questions of ecosystem structure or function.

International-scale programs and portals, such as the Organization for Economic Co-Operation and Development (OECD; Vollenweider and Kerekes 1982), Global Lakes Observatory Network (GLEON; Weathers et al. 2013), and Water Information System for Europe (WISE), merge global data, but lack consistency in sampling design, data collection, and quality control (Table 1). NSFfunded collaborative research projects have also worked at large scales (e.g., Lotic Intersite Nitrogen eXperiment [LINX]; Peterson et al. 2001, Mulholland et al. 2008) and have spearheaded standardized, network experimentation studies (e.g., STReam Experimental Observatory Network [STREON]; Utz et al. 2013). Researchers in many of these programs evaluate aquatic ecosystems across time or space, but their ability to expand data to multiple scales is limited because many programs are site-specific (LTER, ELA), lack temporal coverage (NARS, LINX), or lack consistent methods (LTER, GLEON).

The current direction of ecological research is to address questions covering multiple scales and levels of complexity. This approach requires sampling strategies designed for comparability and extrapolation across disparate ecosystems and regions coupled with the ability to identify processes affecting regime shifts within sites (Heffernan et al. 2014, Rüegg et al. 2014). Missing elements from previous work needed to answer large-scale ecological questions include well organized data management and retrieval systems capable of sharing real-time data (Aronova et al. 2010), comparable measurements and standard methods over various scales (Johnson et al. 2010), and the ability to scale to regional, continental, and global scales.

The National Ecological Observatory Network (NEON) is the first continental-scale ecological observation system designed to collect data focused on drivers of (i.e., climate change, land use, invasive species) and responses to (i.e., biodiversity, biogeochemistry, ecohydrology, infectious disease) change needed to address the "Grand Challenges in Environmental Sciences" (NRC 2001). NEON's goal is to enable understanding and forecasting of the effects of large-scale changes on natural resources over long time periods by combining site-based data (terrestrial, atmospheric, and aquatic instrumentation and field sampling) with remotely sensed data (airborne observations) to provide a range of scaled data products. Data will be collected at 106 sites across 20 ecoclimatic domains, 19 of which contain aquatic sites, delineated to maximize the representation of continental-scale environmental variability (Keller et al. 2008). Thirty-six of these sites are aquatic
(29 streams/large rivers and 7 ponds/lakes), and 10 of 36 include downstream STREON sites (Fig. 1; Utz et al. 2013). NEON sites include 'core' sites, at which data will be gathered over a period of $30 \mathrm{y}$, and 'relocatable' sites, which will change every 5 to $7 \mathrm{y}$ to capture changing ecological phenomena across gradients. Data collected at NEON aquatic sites encompass physical, hydrogeological, chemical, and biological variables. Data collection combines continuously monitoring instrumentation with field observations (Utz et al. 2013). All NEON data are open access and available via a web portal immediately after analysis and rigorous quality assurance/quality control validation (Taylor and Loescher 2013).

In this BRIDGES cluster, we explore cases in which NEON aquatics data and infrastructure can be used to expand ecological research programs and questions across multiple scales, from small to large watershed studies (see below, Sobczak and Raymond 2015). McDowell (2015) discusses the challenges and opportunities of such a research platform. We focus on 2 Grand Challenges: biodiversity (aquatic microbial ecology) and ecohydrology (large river ecology) to illustrate the breadth of potential uses and how researchers can build on the NEON platform at multiple scales.

\section{STREAM MICROBIAL ECOLOGY}

The microbiota of stream ecosystems drive nutrientcycling dynamics with a disproportionally strong influence at the landscape scale (Hynes 1975, Fisher et al. 1998). Streams are conduits of water, organic C, and nutrients across the landscape and are prominent locations of microbially mediated $C$ and nutrient processing, uptake, and transport (Vannote et al. 1980, Peterson et al. 2001, Mulholland et al. 2008). The importance of heterotrophic microbial C cycling in streams is well established. Microbiota can contribute 22 to $27 \%$ of total leaf mass loss directly (Hieber and Gessner 2002). Indirectly, microbiota feed invertebrates that cause physical loss of coarse organic material (Hall and Meyer 1998). When considering all ecosystem components, microbial transformations of $\mathrm{C}$ are a main contributor to whole-stream respiration and $\mathrm{C}$ flow to higher trophic levels (Lindeman 1942, Meyer 1994, Tank et al. 2010), and whole-stream respiration strongly affects nutrient uptake and export (Fellows et al. 2006, Valett et al. 2008).

Stream ecologists have a history of interest in microbial processes and of presenting and testing concepts that link biodiversity and ecosystem processes at organismal, reach, and landscape scales. However, little research has been done on the microbial biodiversity of stream habitats, despite widespread use of molecular methods to evaluate microbial structure and function in ecosystems (Findlay 2010). Current advances in molecular methods will enable researchers to quickly fill gaps in baseline descriptive data and to move toward testing hypotheses relating microbial biodiversity to stream ecosystem processes. 


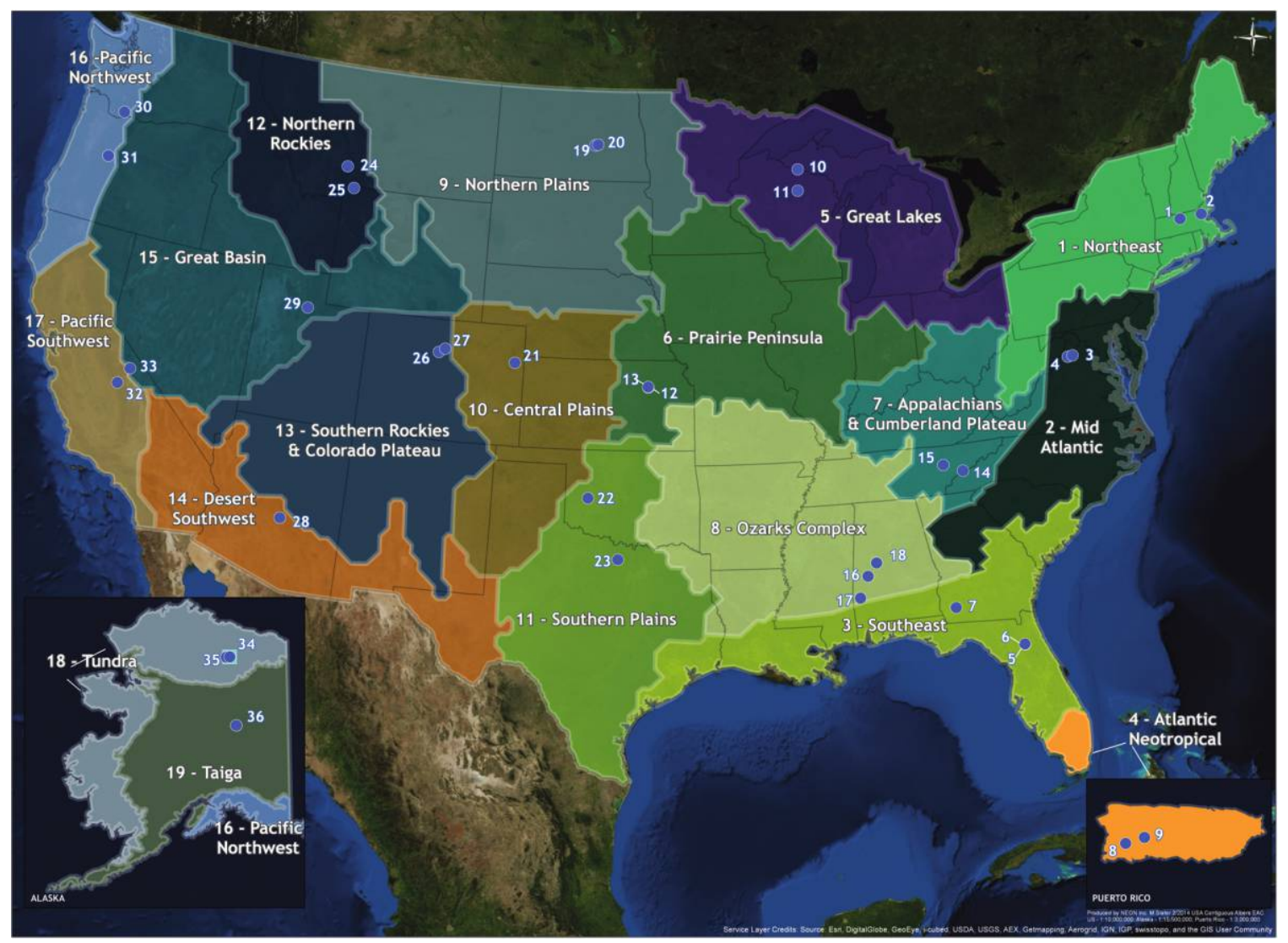

Figure 1. Map of National Ecological Observatory Network (NEON) North American domains and associated candidate aquatic sites. Site numbers correspond to site names, as follows: 1. West Branch Bigelow Brook, Massachusetts, 2. Sawmill Brook, Massachusetts, 3. Mill Run, Virginia*, 4. Posey Creek, Virginia, 5. Suggs Lake, Florida, 6. Barco Lake, Florida, 7. Ichawaynochaway Creek, Georgia, 8. Rio Cupeyes, Puerto Rico*, 9. Rio Guilarte, Puerto Rico, 10. Crampton Lake, Wisconsin, 11. Pickerel Creek, Wisconsin, 12. Kings Creek, Kansas*, 13. McDowell Creek, Kansas, 14. LeConte Creek, Tennessee, 15. Walker Branch, Tennessee*, 16. Black Warrior River, Alabama, 17. Lower Tombigbee River, Alabama, 18. Mayfield Creek, Alabama*, 19. Prairie Pothole, North Dakota, 20. Prairie Lake, North Dakota. 21. Arikaree River, Colorado, 22. South Pond, Oklahoma, 23. Pringle Creek, Texas, 24. Bozeman Creek, Montana, 25. Blacktail Deer Creek, Wyoming, 26. West Saint Louis Creek, Colorado, 27. Como Creek, Colorado, 28. Sycamore Creek, Arizona*, 29. Red Butte Creek, Utah, 30. East Branch Planting Creek, Oregon, 31. McRae Creek, Oregon*, 32. Providence Creek, California, 33. Convict Creek, California*, 34. Toolik Lake, Alaska, 35. Oksrukuyik Creek, Alaska*, 36. Caribou Creek, Alaska*. * indicates colocated NEON Aquatic and STReam Experimental Observatory Network (STREON) sites.

Microbial diversity is relatively understudied in stream habitats, but numerous individual surveys or experiments have addressed microbial diversity in stream ecosystems. A full review of these studies is beyond the scope of our paper, but we take this opportunity to mention several studies that are of general interest. The stream water column carries a dynamic assemblage of terrestrially derived and aquatic bacterial taxa that may track seasonal and event-driven water chemistry (Bell et al. 1982, Crump et al. 2012). Epilithic biofilm diversity also varies temporally, by season (Hullar et al. 2006), and via successional dynamics (Besemer et al. 2007). Successional patterns also occur on leaf biofilms as decomposition progresses (Suberkropp et al. 1983, Gessner et al. 1993, Wymore et al. 2013). Biofilm assemblages differ among leaf, rock, sediment, and water-column habitats, even within the same stream reach (Hullar et al. 2006, Beier et al. 2008, Larouche et al. 2012). Microbial diversity is correlated with ecosystem functions, e.g., bacterial productivity or nutrient uptake (Judd et al. 2006, Adams et al. 2010). Experimental studies are less common than descriptive studies, but they indicate increasing epilithic bacterial diversity and faster biofilm $\mathrm{C}$ uptake in response to increasingly heterogeneous bed flow dynamics (Singer et al. 2010). When aquatic ecosystems are altered, microbial diversity and activity may respond dramatically; e.g., the sediment bacterial community can differ downstream of a wastewater treatment plant (Wakelin et al. 2008), drought can have lasting impacts on stream sediment bacterial diversity (Rees et al. 2006), and fungal communities can be homogenized following exposure to heavy metal contamination (Sridhar et al. 2008). Microbes are diverse and 
dynamic. Therefore, they are responsive to factors that threaten streams at reach and landscape scales; e.g., channel engineering, altered flow regime, temperature, $\mathrm{pH}$, and water chemistry (Malmqvist and Rundle 2002).

The NEON platform will enable evaluation of multiscale stream ecosystem dynamics in space and time. For example, microbial diversity data collected during the STREON whole-stream nutrient addition will be useful in identifying when and where microbial diversity is most sensitive to nutrient addition. Experiments have been done to test effects of elevated nutrient concentration on microbial diversity, but their results differ. A clear shift in bacterial assemblage composition toward dominance of certain taxa caused a decrease in biofilm diversity after dissolved nutrient concentrations were doubled (Van Horn et al. 2011). Added nutrients can also influence fungal diversity (Gulis and Suberkropp 2003). However, increased organic $\mathrm{C}$ may have a stronger effect than increased inorganic nutrients on microbial communities (Olapade and Leff 2006), and inorganic nutrient effects may be secondary to seasonal heterogeneity (Olapade and Leff 2005) or even undetectable (Findlay and Sinsabaugh 2003). In sum, effects of nutrient addition on stream microbial communities can be site or time specific. However, context-specific effects are difficult to tease apart because studies are typically site specific and not comparable because of inconsistent methods across diverse sites and times. Microbial diversity data collected during the STREON whole-stream nutrient-addition experiments will allow scientists to move beyond site-specific interpretation.

Overall, the NEON project and STREON experiment will provide data on microbial abundance and diversity from dominant substrates in streams across the USA-a valuable resource. Collection and analysis of these data with standardized methods at multiple sites and numerous time points at each site will enable researchers to address questions about microbial biogeography and temporal variability. Furthermore, concurrent data on stream physiochemical factors, abundance, diversity of higher trophic levels, and whole-stream ecosystem processing rates (e.g., dissolved organic matter flux; Sobczak and Raymond 2015), will enable researchers to link microbial diversity and microbial processes within a wholestream ecosystem context (Findlay 2010).

Studying and interpreting the role of microbial life at stream reach and landscape scales are challenging, but the opportunities presented by this type of research are exciting. Microbial life is a key component of the organicmatter and nutrient-cycling processes, food webs, and biodiversity of aquatic ecosystems, and microbial diversity data collected as part of the NEON aquatics program are an example of the potential to inform mechanistic hypotheses of aquatic ecosystem function at multiple spatial and temporal scales (McDowell 2015).

\section{LARGE RIVER ECOLOGY}

The NEON aquatics program is focused primarily on wadeable streams, but the design also includes 3 nonwadeable sites, 2 of which are on large rivers in Alabama, USA. These sites are nested within the Mobile River drainage basin along a hydrogeomorphic gradient in river size from a wadeable stream site (Site 18; Fig. 1) to the Black Warrior-Tombigbee River system (Sites 16 and 17; Fig. 1). Allocation of NEON resources to these systems is in recognition of the need to document the influence of climate change, landuse alteration, and aquatic invasive species along an ecohydrologic gradient. The reasons for studying large rivers have become so diverse and of interest for such a wide range of applications that use of the NEON infrastructure to support longterm data collection on large rivers is particularly timely.

Advances in data collection using continuously monitoring sensors deployed on buoys or other stationary structures for water monitoring will allow researchers to circumvent some of the previous limitations of sampling large rivers and increase the temporal resolution of measurements (Cohen et al. 2013). NEON is collaborating with the US Army Corps of Engineers in placing sensors at the Alabama River sites near USGS gauging stations for real-time discharge monitoring. NEON instrumentation will provide long-term measurements of surfacewater variables (water temperature, dissolved $\mathrm{O}_{2}$, turbidity, $\mathrm{pH}$, conductivity, chlorophyll $a, \mathrm{NO}_{3}{ }^{-}$, and fluorescent dissolved organic matter) that have never been measured continuously, in full, for multiple years in a large US river. In addition, surface-water and sediment chemistry, river bathymetry, and biotic community dynamics (fish, macroinvertebrates, algae, and prokaryotes) will be measured at various time scales.

In all, the NEON large-river sampling design provides researchers with an opportunity to broaden the spatial scale at which stream theory is tested by making ecological measurements concurrently along a hydrologic gradient. The sites along this gradient experience similar geochemical and climatological conditions, but may respond differently to disturbance events (e.g., invasive species, floods, landuse change) or seasonality because of differences in geomorphic structure associated with the widening and deepening of larger river channels. This approach has been particularly successful in free-flowing rivers, where it has been used to test conceptual models, such as the River Continuum Concept (RCC; Vannote et al. 1980), the Flood Pulse Concept (FPC; Junk et al. 1989), and stoichiometric theory (Elser et al. 1996). Researchers have challenged these current paradigms in river ecology, finding either little support for patterns predicted by the RCC for the downstream portions of a river network (Huryn et al. 2002) or suggesting modifications of FPC to increase global applicability (Puckridge et al. 1998). Also in contrast to predicted patterns (Alexan- 
der et al. 2000), Tank et al. (2008) found an unexpectedly large influence of biota on $\mathrm{N}$ retention in downstream reaches in nutrient uptake kinetics along a gradient from low- to high-order rivers in a single watershed.

Variation in ecological processes along a large river is a response to a hierarchically structured set of variables that are directly or indirectly controlled by variation in geomorphic structure, including water depth and velocity, sediment particle size, and abundance of planktonic algal cells or suspended sediment. These variables can constrain microbial community structure at broad spatial scales (Tatariw et al. 2013), and control the supply of labile organic matter in river $\mathrm{C}$ pools (Mortillaro et al. 2012). Spatial variation along large rivers is coupled with facets of flow regime that can be complex and system specific. These factors make it difficult to link life-history traits with alterations in hydrologic variables without high-frequency measurements (Puckridge et al. 1998). Cohen et al. (2013) required very high temporal resolution of river data (on the scale of minutes) to distinguish between biotic and abiotic mechanisms of nutrient retention in a Florida river, suggesting that NEON's continuous monitoring on the Black Warrior-Tombigbee River system is a strong approach for documenting the influence of multiple variables on ecosystem processes.

Our challenge as a scientific community is to test and expand basic theory to generate new ideas regarding the ecology of large, heavily modified rivers (Stanley et al. 2010). Measurements of $C$ cycling and foodweb structure in impounded rivers have highlighted regional-scale control of floodplain and planktonic subsidies created by anthropogenic alterations in geomorphic form (Thomas et al. 2005, Hoeinghaus et al. 2007, Ochs et al. 2010, 2013, Castello et al. 2013). NEON's river monitoring program will document variability in material loadings and faunal population structure, allowing researchers to contrast patterns in free-flowing streams with those of managed systems. These data will be available for validation of river modeling efforts, such as that of Global NEWS 2 (Mayorga et al. 2010), which link biological processes in river networks to coastal estuaries. This linkage is critical for addressing concerns related to eutrophication and declining commercial fisheries, and governmental monitoring agencies are making a strong plea for increased collaborative efforts to address applied research questions with a cohesive, broad-scale sampling design (McCain 2013). Data collected at the NEON river locations will be similar to those used in other ecosystems for flood-hazard assessment, estimating foodweb structure, and identifying sources of suspended solids to assess abatement strategies. Thus, NEON data will contribute to watershed management decisions (Ghizzoni et al. 2012, Turner and Edwards 2012, Westhorpe and Mitrovic 2012, Zhang et al. 2012, Saintilan et al. 2013).
The NEON sampling effort in large rivers can be considered a scaffold upon which researchers can build their own program for answering a variety of research questions. Current interest in large-river ecology includes partitioning sediment-associated and water-column metabolic activity, determining the fate of primary production in the water column, linking river geomorphic structure to nutrient cycling, and considering the role of hydrologic retention in influencing pelagic microorganisms. In addition to these current questions, NEON's large-river sampling design could be used to inform yet-unconsidered, future research efforts.

\section{Conclusion}

NEON is a comprehensive platform that provides new opportunities for implementing research that spans spatial and temporal scales. Information collected at NEON aquatic sites can be linked with atmospheric, terrestrial, and airborne observations, documenting ecological change in a more comprehensive manner than is often possible within individual research programs. Access to NEON sites, instrumentation, and data will provide a mechanism for linking stream ecosystem structure and function with landscape and climatic drivers (Sobczak and Raymond 2015). The addition of the NEON platform as an opensource tool will provide researchers with unprecedented access to high-quality data generated using standardized collection methods across various scales. These data will enable researchers to answer novel ecological questions and integrate their own research into the NEON platform.

\section{ACKN OWLEDGEMENTS}

NEON is a project sponsored by the NSF and managed under cooperative agreement by NEON, Inc. This material is based upon work supported by the NSF under the following grants: EF-1029808, EF-1138160, EF-1150319, and DBI-0752017. Any opinions, findings, and conclusions or recommendations expressed in this material are those of the authors and do not necessarily reflect the views of the NSF.

\section{LITERATURE CITED}

Adams, H. E., B. C. Crump, and G. W. Kling. 2010. Temperature controls on aquatic bacterial production and community dynamics in arctic lakes and streams. Environmental Microbiology 12:1319-1333.

Alexander, R. B., R. A. Smith, and G. E. Schwarz. 2000. Effect of stream channel size on the delivery of nitrogen to the Gulf of Mexico. Nature 403:758-761.

Allan, J. D., and L. B. Johnson. 1997. Catchment-scale analysis of aquatic ecosystems. Freshwater Biology 37:107-111.

Aronova, E., K. S. Baker, and N. Oreskes. 2010. Big science and big data in biology: from the International Geophysical Year through the International Biological Program to the Long 
Term Ecological Research (LTER) Network, 1957-present. Historical Studies in the Natural Sciences 40:183-224.

Beier, S., K. P. Witzel, and J. Marxsen. 2008. Bacterial community composition in central European running waters examined by temperature gradient gel electrophoresis and sequence analysis of $16 \mathrm{~S}$ rRNA genes. Applied and Environmental Microbiology 74:188-199.

Bell, C. R., M. A. Holder-Franklin, and M. Franklin. 1982. Seasonal fluctuations in river bacteria as measured by multivariate statistical analysis of continuous cultures. Canadian Journal of Microbiology 28:959-975.

Besemer, K., G. Singer, R. Limberger, A. K. Chlup, G. Hochedlinger, I. Hödl, C. Baranyi, and T. J. Battin. 2007. Biophysical controls on community succession in stream biofilms. Applied and Environmental Microbiology 73:49664974.

Beven, K. J., E. F. Wood, and M. Sivapalan. 1988. On hydrological heterogeneity: catchment morphology and catchment response. Journal of Hydrology 100:353-375.

Bormann, F. H., and G. E. Likens. 1969. The watershed-ecosystem concept and studies of nutrient cycles. Pages 49-79 in G. M. Van Dyne (editor). The ecosystem concept in natural resource management. Academic Press, New York.

Carpenter, S. R., J. J. Cole, J. R. Hodgson, J. F. Kitchell, M. L. Pace, D. Bade, K. L. Cottingham, T. E. Essington, J. N. Houser, and D. E. Schindler. 2001. Trophic cascades, nutrients, and lake productivity: whole-lake experiments. Ecological Monographs 71:163-186.

Carpenter, S. R., J. F. Kitchell, J. R. Hodgson, P. A. Cochran, J. J. Elser, M. M. Elser, D. M. Lodge, D. Kretchmer, X. He, C. N. von Ende. 1987. Regulation of lake primary productivity by food web structure. Ecology 68:1863-1876.

Castello, L., D. G. McGrath, L. L. Hess, M. T. Coe, P. A. Lefebvre, P. Petry, M. N. Macedo, V. F. Renó, and C. C. Arantes. 2013. The vulnerability of Amazon freshwater ecosystems. Conservation Letters 6:217-229.

Cohen, M. J., M. J. Kurz, J. B. Heffernan, J. B. Martin, R. L. Douglass, C. R. Foster, and R. G. Thomas. 2013. Diel phosphorus variation and the stoichiometry of ecosystem metabolism in a large spring-fed river. Ecological Monographs 83:155-176.

Crump, B. C., L. A. Amaral-Zettler, and G. W. Kling. 2012. Microbial diversity in arctic freshwaters is structured by inoculation of microbes from soils. ISME Journal 6:16291639.

Elser, J. J., D. R. Dobberfuhl, N. A. MacKay, and J. H. Schampel. 1996. Organism size, life history, and N:P stoichiometry. BioScience 46:674-684.

Fellows, C. S., H. M. Valett, C. N. Dahm, P. J. Mulholland, and S. A. Thomas. 2006. Coupling nutrient uptake and energy flow in headwater streams. Ecosystems 9:788-804.

Findlay, S. 2010. Stream microbial ecology. Iournal of the North American Benthological Society 29:170-181.

Findlay, S., and R. L. Sinsabaugh. 2003. Response of hyporheic biofilm metabolism and community structure to nitrogen amendments. Aquatic Microbial Ecology 33:127-136.

Fisher, S. E. G., N. B. Grimm, E. Martí, R. M. Holmes, and J. B. Jones. 1998. Material spiraling in stream corridors: a telescoping ecosystem model. Ecosystems 1:19-34.
Frissell, C. A., W. J. Liss, C. E. Warren, and M. D. Hurley. 1986. A hierarchical framework for stream habitat classification: viewing streams in a watershed context. Environmental Management 10:199-214.

Gessner, M. O., M. Thomas, A.-M. Jean-Louis, and E. Chauvet. 1993. Stable successional patterns of aquatic hyphomycetes on leaves decaying in a summer cool stream. Mycological Research 97:163-172.

Ghizzoni T., G. Roth, and R. Rudari. 2012. Multisite flooding hazard assessment in the Upper Mississippi River. Journal of Hydrology 412:101-113.

Gulis, V., and K. Suberkropp. 2003. Leaf litter decomposition and microbial activity in nutrient-enriched and unaltered reaches of a headwater stream. Freshwater Biology 48:123-134.

Hall, R. O., and J. L. Meyer. 1998. The trophic significance of bacteria in a detritus-based stream food web. Ecology 79: 1995-2012.

Heffernan, J. B., P. A. Soranno, M. J. Angilletta, L. B. Buckley, D. S. Gruner, T. H. Keitt, J. R. Kellner, J. S. Kominoski, A. V. Rocha, J. Xiao, T. K. Harms, S. J. Goring, L. E. Koenig, W. H. McDowell, H. Powell, A. D. Richardson, C. A. Stow, R. Vargas, and K. C. Weathers. 2014. Macrosystems ecology: understanding ecological patterns and processes at continental scales. Frontiers in Ecology and the Environment 12:5-14.

Hieber, M., and M. O. Gessner. 2002. Contribution of stream detritivores, fungi, and bacteria to leaf breakdown based on biomass estimates. Ecology 83:1026-1038.

Hirsch, R. M., W. M. Alley, and W. G. Wilbur. 1988. Concepts for a National Water-Quality Assessment Program. US Geological Survey Circular 1021. US Geological Survey, Reston, Virginia.

Hobbie, J. E., S. R. Carpenter, N. B. Grimm, J. R. Gosz, and T. R. Seastedt. 2003. The US Long Term Ecological Research Program. BioScience 53:21-32.

Hoeinghaus, D. J., K. O. Winemiller, and A. A. Agostinho. 2007. Landscape-scale hydrologic characteristics differentiate patterns of carbon flow in large-river food webs. Ecosvstems 10:1019-1033.

Hullar, M. A. J., L. A. Kaplan, and D. A. Stahl. 2006. Recurring seasonal dynamics of microbial communities in stream habitats. Applied and Environmental Microbiology 72:713-722.

Huryn, A. D., R. H. Riley, R. G. Young, C. J. Arbuckle, and K. Peacock. 2002. Natural-abundance stable $\mathrm{C}$ and $\mathrm{N}$ isotopes indicate weak upstream-downstream linkage of food webs in a grassland river. Archiv für Hydrobiologie 153: 177-196.

Huryn, A. D., K. A. Slavik, R. L. Lowe, S. M. Parker, D. S. Anderson, and B. J. Peterson. 2005. Landscape heterogeneity and the biodiversity of Arctic stream communities: a habitat template analysis. Canadian Journal of Fisheries and Aquatic Sciences 62:1905-1919.

Hynes, H. B. N. 1975. The stream and its valley. Verhandlungen der Internationalen Vereinigung für theoretische und angewandte Limnologie 19:1-15.

Johnson, J. C., R. R. Christian, J. W. Brunt, C. R. Hickman, and R. B. Waide. 2010. Evolution of collaboration within the US Long Term Ecological Research Network. BioScience 60: 931-940. 
Johnson, W. E., and J. R. Vallentyne. 1971. Rationale, background, and development of experimental lake studies in northwestern Ontario. Journal of the Fisheries Research Board of Canada 28:123-128.

Judd, K. E., B. C. Crump, and G. W. Kling. 2006. Variation in dissolved organic matter controls bacterial production and community composition. Ecology 87:2068-2079.

Junk, W. J., P. B. Bayley, and R. E. Sparks. 1989. The flood pulse concept in river-floodplain systems. Proceedings of the International Large River Symposium (LARS). Pages 110-127 in D. P. Dodge (editor). Canadian Special Publications of Fisheries and Aquatic Sciences, Ottawa, Canada.

Keller, M., D. S. Schimel, W. W. Hargrove, and F. M. Hoffman. 2008. A continental strategy for the National Ecological Observatory Network. Frontiers in Ecology and the Environment 6:282-284.

Larouche, J. R., W. B. Bowden, R. Giordano, M. B. Flinn, and B. C. Crump. 2012. Microbial biogeography of arctic streams: exploring influences of lithology and habitat. Frontiers in Microbiology 3:309.

Lindeman, R. L. 1942. The trophic-dynamic aspect of ecology. Ecology 23:399-417.

Likens, G. E., F. H. Bormann, R. S. Pierce, J. S. Eaton, and N. M. Johnson. 1977. Biogeochemistry of a forested ecosystem. Springer-Verlag, New York.

Malmqvist, B., and S. Rundle. 2002. Threats to the running water ecosystems of the world. Environmental Conservation 2:134-153.

Mayorga, E., S. P. Seitzinger, J. A. Harrison, E. Dumont, A. H. W. Beusen, A. F. Bouwman, B. M. Fekete, C. Kroeze, and G. Van Drecht. 2010. Global nutrient export from WaterSheds 2 (NEWS 2): Model development and implementation. Environmental Modelling and Software 25:837-853.

McCain, K. N. S. 2013. Moving large river ecology from past theories to future actions: a review. Reviews in Fisheries Science 21:39-48.

McClain, M. E., E. W. Boyer, C. L. Dent, S. E. Gergel, N. B. Grimm, P. M. Groffman, S. C. Hart, J. W. Harvey, C. A. Johnston, E. Mayorga, W. H. McDowell, and G. Pinay. 2003. Biogeochemical hot spots and hot moments at the interface of terrestrial and aquatic ecosystems. Ecosystems 6:301-312.

McDonnell, J. J., M. Sivapalan, K. Vaché, S. Dunn, G. Grant, R. Haggerty, C. Hinz, R. Hooper, J. Kirchner, M. L. Roderick, J. Selker, and M. Weiler. 2007. Moving beyond heterogeneity and process complexity: a new vision for watershed hydrology. Water Resources Research 43:1-6.

McDowell, W. H. 2015. NEON and STREON: opportunities and challenges for the aquatic sciences. Freshwater Science 33:386-391.

Messer, J. J., R. A. Linthurst, and W. S. Overton. 1991. An EPA program for monitoring ecological status and trends. Environmental Monitoring and Assessment 17:67-78.

Meyer, J. L. 1994. The microbial loop in flowing waters. Microbial Ecology 28:195-199.

Mortillaro, J. M., F. Rigal, H. Rybarczyk, M. Bernardes, G. Abril, and T. Meziane. 2012. Particulate organic matter distribution along the lower Amazon River: addressing aquatic ecology concepts using fatty acids. PLoS ONE 7:e46141.
Mulholland, P. J., A. M. Helton, G. C. Poole, R. O. Hall, S. K. Hamilton, B. J. Peterson, J. L. Tank, L. R. Ashkenas, L. W. Cooper, C. N. Dahm, W. K. Dodds, S. E. G. Findlay, S. V. Gregory, N. B. Grimm, S. L. Johnson, W. H. McDowell, J. L. Meyer, H. M. Valett, J. R. Webster, C. P. Arango, J. J. Beaulieu, M. J. Bernot, A. J. Burgin, C. L. Crenshaw, L. T. Johnson, B. R. Niederlehner, J. M. O’Brien, J. D. Potter, R. W. Sheibley, D. J. Sobota, and S. M. Thomas. 2008. Stream denitrification across biomes and its response to anthropogenic nitrate loading. Nature 452:202-246.

NRC (National Research Council). 2001. Grand challenges in environmental sciences. National Academies Press, Washington, DC.

Ochs, C. A., H. E. Capello, and O. Pongruktham. 2010. Bacterial production in the Lower Mississippi River: importance of suspended sediment and phytoplankton biomass. Hydrobiologia 637:19-31.

Ochs, C. A., O. Pongruktham, and P. V. Zimba. 2013. Darkness at the break of noon: phytoplankton production in the Lower Mississippi River. Limnology and Oceanography 58: 555-568.

Olapade, O. A., and L. G. Leff. 2005. Seasonal response of stream biofilm communities to dissolved organic matter and nutrient enrichments. Applied and Environmental Microbiology 71:2278-2287.

Olapade, O. A., and L. G. Leff. 2006. Influence of dissolved organic matter and inorganic nutrients on the biofilm bacterial community on artificial substrates in a northeastern Ohio, USA, stream. Canadian Journal of Microbiology 52: 540-549.

Pace, M. L., J. J. Cole, S. R. Carpenter, and J. F. Kitchell. 1999. Trophic cascades revealed in diverse ecosystems. Trends in Ecology and Evolution 14:483-488.

Paine, R. T. 1980. Food webs: linkage, interaction strength and community infrastructure. Journal of Animal Ecology 49: 666-685.

Palmer, M. A., and N. L. Poff. 1997. The influence of environmental heterogeneity on patterns and processes in streams. Journal of the North American Benthological Society 16: 169-173.

Peterson, B. J., W. M. Wollheim, P. J. Mulholland, J. R. Webster, J. L. Meyer, J. L. Tank, E. Martí, W. B. Bowden, H. M. Valett, A. E. Hershey, W. H. McDowell, W. K. Dodds, S. K. Hamilton, S. Gregory, and D. D. Morrall. 2001. Control of nitrogen export from watersheds by headwater streams. Science 292:86-90.

Power, M. E., R. J. Stout, C. E. Cushing, P. P. Harper, F. R. Hauer, W. J. Matthews, P. B. Moyle, B. Statzner, and I. R. Wais de Badgen. 1988. Biotic and abiotic controls in river and stream communities. Journal of the North American Benthological Society 7:456-479.

Puckridge, J. T., F. Sheldon, K. F. Walker, and A. J. Boulton. 1998. Flow variability and the ecology of large rivers. Marine and Freshwater Research 49:55-72.

Rees, G. N., G. O. Watson, D. S. Baldwin, and A. M. Mitchell. 2006. Variability in sediment microbial communities in a semipermanent stream: impact of drought. Journal of the North American Benthological Society 25:370-378. 
Rosemond, A. D., C. M. Pringle, A. Ramírez, and M. J. Paul. 2001. A test of top-down and bottom-up control in a detritus-based food web. Ecology 82:2279-2293.

Rüegg, J., C. Gries, B. Bond-Lamberty, G. J. Bowen, B. S. Felzer, N. E. McIntyre, P. A. Soranno, K. L. Vanderbilt, and K. C. Weathers. 2014. Completing the data life cycle: using information management in macrosystems ecology research. Frontiers in Ecology and the Environment 12:24-30.

Saintilan, N., K. Rogers, and T. J. Ralph. 2013. Matching research and policy tools to scales of climate-change adaptation in the Murray-Darling, a large Australian river basin: a review. Hydrobiologia 708:97-109.

Scarsbrook, M. R., and C. R. Townsend. 1993. Stream community structure in relation to spatial and temporal variation: a habitat templet study of two contrasting New Zealand streams. Freshwater Biology 29:395-410.

Singer, G., K. Besemer, P. Schmitt-Kopplin, I. Hödl, and T. J. Battin. 2010. Physical heterogeneity increases biofilm resource use and its molecular diversity in stream mesocosms. PLoS ONE 5:e9988.

Sobczak, W. V., and P. A. Raymond. 2015. Watershed hydrology and dissolved organic matter export across time scales: minute to millennium. Freshwater Science 33:392-398.

Southwood, T. R. E. 1988. Tactics, strategies and templets. Oikos 52:3-18.

Sridhar, K. R., F. Bärlocher, R. Wennrich, G. J. Krauss, and G. Krauss. 2008. Fungal biomass and diversity in sediments and on leaf litter in heavy metal contaminated waters of Central Germany. Fundamental and Applied Limnology 171:63-74.

Stanley, E. H., S. M. Powers, and N. R. Lottig. 2010. The evolving legacy of disturbance in stream ecology: concepts, contributions, and coming challenges. Journal of the North American Benthological Society 29:67-83.

Suberkropp, K., T. L. Arsuffi, and J. P. Anderson. 1983. Comparison of degradative ability, enzymatic activity, and palatability of aquatic hyphomycetes grown on leaf litter. Applied and Environmental Microbiology 46:237-244.

Tank, J. L., E. J. Rosi-Marshall, M. A. Baker, and R. O. Hall. 2008. Are rivers just big streams? A pulse method to quantify nitrogen demand in a large river. Ecology 89:2935-2945.

Tank, J. L., E. J. Rosi-Marshall, N. A. Griffiths, S. A. Entrekin, and M. L. Stephen. 2010. A review of allochthonous organic matter dynamics and metabolism in streams. Journal of the North American Benthological Society 29:118-146.

Tatariw, C., E. Chapman, R. A. Sponseller, B. Mortazavi, and J. W. Edmonds. 2013. Denitrification in a mid-sized river: interactions between geomorphology and microbial community structure. Ecology 94:2249-2262.

Taylor, J. R., and H. L. Loescher. 2013. Automated quality control methods for sensor data: a novel observatory approach. Biogeosciences 10:4957-4971.

Thomas, S. A., T. V. Royer, E. B. Snyder, and J. C. Davis. 2005. Organic carbon spiraling in an Idaho river. Aquatic Sciences 67:424-433.
Turner, T. F., and M. S. Edwards. 2012. Aquatic foodweb structure of the Rio Grande assessed with stable isotopes. Freshwater Science 31:825-834.

Utz, R. M., M. R. Fitzgerald, K. J. Goodman, S. M. Parker, H. Powell, and C. L. Roehm. 2013. The National Ecological Observatory Network: an observatory poised to expand spatiotemporal scales of inquiry in aquatic and fisheries science. Fisheries 38:26-35.

Valett, H. M., S. A. Thomas, P. J. Mulholland, J. R. Webster, C. N. Dahm, C. S. Fellows, C. L. Crenshaw, and C. G. Peterson. 2008. Endogenous and exogenous control of ecosystem function: N cycling in headwater streams. Ecology 89:3515-3527.

Van Horn, D. J., R. L. Sinsabaugh, C. D. Takacs-Vesbach, K. R. Mitchell, and C. N. Dahm. 2011. Response of heterotrophic stream biofilm communities to a gradient of resources. Aquatic Microbial Ecology 64:149-161.

Vannote, R. L., G. W. Minshall, K. W. Cummins, J. R. Sedell, and C. E. Cushing. 1980. The river continuum concept. Canadian Journal of Fisheries and Aquatic Sciences 37:130-137.

Vollenweider, R. A., and J. Kerekes. 1982. Eutrophication of waters. Monitoring, assessment and control. OECD Cooperative programme on monitoring of inland waters (eutrophication control). Environment Directorate, Organization for Economic Co-Operation and Development, Paris, France.

Wakelin, S. A., M. J. Colloff, and R. S. Kookana. 2008. Effect of wastewater treatment plant effluent on microbial function and community structure in the sediment of a freshwater stream with variable seasonal flow. Applied and Environmental Microbiology 74:2659-2668.

Weathers, K. C., P. C. Hanson, P. Arzberger, J. Brentrup, J. Brookes, C. C. Carey, E. Gaiser, D. P. Hamilton, G. S. Hong, B. Ibelings, V. Istvánovics, E. Jennings, B. Kim, T. Kratz, F. Lin, K. Muraoka, C. O’Reilly, C. Piccolo, K. C. Rose, E. Ryder, and G. Zhu. 2013. The Global Lake Ecological Observatory Network (GLEON): the evolution of grassroots network science. Bulletin of Limnology and Oceanography 22:71-73.

Westhorpe, D. P., and S. M. Mitrovic. 2012. Dissolved organic carbon mobilisation in relation to variable discharges and environmental flows in a highly regulated lowland river. Marine and Freshwater Research 63:1218-1230.

Williamson, C. E., J. E. Saros, W. F. Vincent, and J. P. Smol. 2009. Lakes and reservoirs as sentinels, integrators, and regulators of climate change. Limnology and Oceanography 54:2273-2282.

Wymore, A. S., Z. G. Compson, C. M. Liu, L. B. Price, T. G. Whitham, P. Keim, and J. C. Marks. 2013. Contrasting rRNA gene abundance patterns for aquatic fungi and bacteria in response to leaf-litter chemistry. Freshwater Science 32:663672.

Zhang Y. S., A. L. Collins, and A. J. Horowitz. 2012. A preliminary assessment of the spatial sources of contemporary suspended sediment in the Ohio River basin, United States, using water quality data from the NASQAN programme in a source tracing procedure. Hydrological Processes 26:326334. 